\title{
Attitude of Farmers towards Crop Insurance in Coochbehar District of West Bengal
}

\author{
S. Chakraborty, S. Ghosh, U. Rai, S. Panda, L. Das, P. K. Pal and S. Mondal* \\ Department of Agicultural Extension, Faculty of Agriculture, \\ Pundibari, Coochbehar, West Bengal, India \\ *Corresponding author
}

\begin{tabular}{|l|}
\hline Ke y w o r d s \\
Agriculture \\
Insurance, \\
Crop Insurance, \\
Insurance
\end{tabular}

\begin{abstract}
A B S T R A C T
Crop yield and income from farm is always under frequent threat of natural disasters. Crop insurance is considered to be a basic instrument for ensuring stability of farm income by promoting and encouraging technology, investment and credit flow. Still it is not much popular among our farmers. Hence, the study was conducted to understand the attitude of the farmers towards crop insurance in the district of Coochbehar in West Bengal. The study was carried out in Mathabhanga-2 and Cooch Behar -2, blocks of Coochbehar district of West Bengal. The state, district and villages were selected purposively. From three villages namely Tenganmari, Khagribari, Bara Simulguri, Baghmara 100 respondents, were selected randomly. The variables like Age, Land holding, Farming experience, Awareness about crop insurance, Land possession type, Gross cropped area, Utilisation of information sources, Satisfaction level, Purpose of adoption, Adoption and Affordability were taken as independent variables whereas, Attitude was taken as dependent variable. Data were collected from individual farmers with interview schedule and processed through co -relation coefficient and multiple regressions. Level of satisfaction with different factors is also measured. The farmers with more gross cropped area have shown negative but significant relation with attitude towards crop insurance whereas, farmers with high satisfaction level and greater affordability have shown positive and significant relation with crop insurance programme. However, combination of all independent variables put together, could only explain $23 \%$ of variance embedded with the dependent variable, attitude of farmers towards crop insurance.
\end{abstract}

\section{Introduction}

Agriculture is considered as the largest industry in the world and the major source of social and economic growth. However, Crop yield and income from farm is always under the threat of natural disasters such as drought, cyclone, floods, landslides, storms, earthquake etc. All these events severely affect our farmers' income and are mostly not under their control. Hence, it is totally an uncertain business and a risky affair for farmers.

Crop insurance is considered to be a basic instrument for ensuring stability of farm income by promoting and encouraging technology, investment and credit flow. The 
basic idea behind the crop insurance is that the loss incurred by the few farmers is technically shared by others in an area, engaged in similar activities. Also, resources accumulated in good years are being compensated with losses incurred in bad years. The first ever crop insurance scheme was launched in the year 1972.Between the year 1985 - 2013, the performance of the crop insurance schemes has been modest. In June 2016 the government has launched PMFBY (Prime Minister Fasal Bima Yojana) with the objective of "one nation, one scheme". The scheme has attempted to reduce the insurance premium to some extent and improve the expansion of insurance coverage by including more crops and risk factors into consideration but still it has faced a sharp decline in the take up of the insurance scheme by farmers during the year 2017-18.

The present study has thus been conducted to understand the attitude of the farmers towards crop insurance in the district of Coochbehar in West Bengal.

\section{Materials and Methods}

The present study was carried out with the farmers of Coochbehar 2 and Mathabhanga 2 block of Coochbehar district in the state of West Bengal. Random sampling technique was adopted for the selection of respondents from the purposively selected villages namely, Tenganmari, Khagribari, Bara Simulguri and Baghmara and 25 numbers of respondents were selected from each village. Thus, a total of 100 respondents were selected for the purpose of the study. The male or female head were chosen for interview, which was done purposely for accurate collection of information.

The variables like Age, Land holding, Farming experience, Awareness about crop insurance, Land possession type, Gross cropped area, Utilisation of information sources, Satisfaction level, Purpose of adoption, Adoption and Affordability were taken as independent variables whereas, Attitude was taken as dependent variable.

A structured interview schedule was prepared as well as pre tested before going for final data collection. The data were than collected with the help of structured interview schedule, through personal interview method.

\section{Results and Discussion}

Table 1 depicts that the independent variable Gross cropped area of the respondent has shown a negative but significant relation with their attitude towards crop insurance because the farmers with more land, of this study area use crop diversification as a risk mitigation tool hence less interested in crop insurance. However, variables like Satisfaction level as well as Affordability recorded a positive as well as significant relation with the attitude of the respondents towards crop insurance because once a customer is satisfied, would always remain loyal to the product similarly affordability of paying premium has also encouraged the farmers and hence farmers have shown a positive attitude.

The table 2 shows that the independent variables like Gross cropped area, Satisfaction level and Affordability have contributed significantly on the dependent variable Attitude towards crop insurance. With the $\mathrm{R}^{2}$ value being only $23 \%$, it is to infer that, the combination of these six independent variables could only explain $23 \%$ of the variance embedded with the dependent variable Attitude of the farmers towards crop insurance. Hence, there must be many more independent variables that remained unidentified in the study but contributed in defining the attitude of the farmers towards crop insurance. 
Table.1 Coefficient of correlation between attitudes of the respondents with selected independent variables

\begin{tabular}{|l|l|}
\hline Independent Variables & Attitude \\
\hline Land Holding & -0.046 \\
\hline Age & 0.001 \\
\hline Farming Experience & -0.130 \\
\hline Awareness about Crop Insurance & -0.013 \\
\hline Gross Cropped Area & $\mathbf{- 0 . 2 5 5 ^ { * }}$ \\
\hline Land possession Type (own/ lease or both) & -0.023 \\
\hline Satisfaction Level & $\mathbf{0 . 2 7 5}$ \\
\hline Utilisation of information source & -0.008 \\
\hline Attitude & 1 \\
\hline Purpose of adoption & -0.117 \\
\hline Adoption & -0.133 \\
\hline Affordability & $\mathbf{0 . 2 2 4}$ \\
\hline
\end{tabular}

*Significant at 5\% level, **Significant at $1 \%$ level

Table.2 Regression analysis between dependent variable attitude and various independent variables

\begin{tabular}{|l|c|c|c|c|c|}
\hline \multirow{2}{*}{ Variables } & \multicolumn{2}{|c|}{$\begin{array}{c}\text { Unstandardized } \\
\text { Coefficients }\end{array}$} & \multicolumn{2}{c|}{$\begin{array}{c}\text { Standardized } \\
\text { Coefficients }\end{array}$} & \multirow{2}{*}{ Sig. } \\
\cline { 2 - 6 } & $\mathrm{B}$ & Std. Error & Beta & & \\
\hline Age & .027 & .030 & .095 & 0.906 & .367 \\
\hline Farming Experience & .194 & .119 & .224 & 1.636 & .105 \\
\hline Gross Cropped Area & $\mathbf{. 4 6 1}$ & $\mathbf{. 1 4 9}$ & $\mathbf{. 4 4 6}$ & $\mathbf{- 3 . 1 0 3} *$ & $\mathbf{. 0 0 3}$ \\
\hline Satisfaction Level & $\mathbf{. 4 4 2}$ & $\mathbf{. 1 2 5}$ & $\mathbf{. 3 3 6}$ & $\mathbf{3 . 5 4 0} * *$ & $\mathbf{. 0 0 1}$ \\
\hline Utilisation of information source & .060 & .107 & .053 & .561 & .576 \\
\hline Affordability & $\mathbf{. 5 4 9}$ & $\mathbf{. 2 1 9}$ & $\mathbf{. 2 4 1}$ & $\mathbf{2 . 5 0 0 *}$ & $\mathbf{. 0 1 4}$ \\
\hline
\end{tabular}

$\mathrm{R}^{2}=23 \%$

Table.3 Satisfaction with insurance

\begin{tabular}{|l|l|c|c|c|c|}
\hline $\begin{array}{l}\text { Sl. } \\
\text { No. }\end{array}$ & Factors / Variables & Satisfied (2) & $\begin{array}{c}\text { Somewhat } \\
\text { Satisfied (1) }\end{array}$ & $\begin{array}{c}\text { Not Satisfied } \\
\text { (0) }\end{array}$ & Total \\
\hline $\mathbf{1}$ & Cost of insurance product & 15 & 60 & 25 & 100 \\
\hline $\mathbf{2}$ & Manner of selling & 16 & 57 & 27 & 100 \\
\hline $\mathbf{3}$ & Speed of compensation procedure & 37 & 42 & 21 & 100 \\
\hline $\mathbf{4}$ & Departmental policies/administrative difficulties & 10 & 60 & 30 & 100 \\
\hline $\mathbf{5}$ & Amount of compensation paid & 7 & 43 & 50 & 100 \\
\hline $\mathbf{6}$ & Level of government involvement & 33 & 40 & 27 & 100 \\
\hline $\mathbf{7}$ & Level of coverage of various hazards & 34 & 41 & 25 & 100 \\
\hline $\mathbf{8}$ & Feeling of security & 30 & 47 & 23 & 100 \\
\hline $\mathbf{9}$ & Accessibility of insurance and bank agencies & 18 & 66 & 16 & 100 \\
\hline $\mathbf{1 0}$ & Time taken for insurance settlement & 29 & 41 & 30 & 100 \\
\hline Mean satisfaction level $=\mathbf{0 . 9 5}$ & & & & \\
\hline
\end{tabular}


An introspection of table 3 reveals that when the farmers were asked about different factors responsible for their satisfaction with insurance, it was found that, the mean satisfaction level is not convincing, it is only $0.95 \%$ with all factors taken into consideration. Hence, it can be concluded that all the independent variables together were not sufficient towards characterizing satisfaction level of the respondents. So, there is an ample scope of further research in order to find out the factors which can lead to farmers satisfaction and popularity of the scheme.

In conclusion the weather conditions are beyond the control of the farmers and as such crop insurance is a catalytic tool to manage the production risk of the crop, still it has yet not gained popularity among the farmers. The actual penetration of crop insurance depends on how and to what extent the farmers perceive it, as beneficial to them, which actually build their overall attitude towards the scheme. However, the study revealed that there are factors like Gross cropped area, Satisfaction level and Affordability of the farmers also that affect the attitude of the farmers towards this scheme. There must be many other factors also, which do influence the attitude of the farmers but unfortunately the study could not bring them into light. Hence, there is a huge scope for further study. Further, the farmers should also believe that the terms of the insurance are reasonable and have the confidence that there would be timely settlement of claims for a required positive attitude towards crop insurance.

\section{References}

Goudappa S.B., Reddy B. S. and Chandrashekhar S.M. (2012). Farmers Perception and Awareness about Crop Insurance in Karnataka. Indian Research Journal of Extension Education, Special Issue (Volume II): 218-222.

Narayanan A. G. Vand Saravanan T.P (2011), A Study on Customers' Perception towards General Insurance Products (Livestock \& Crop Insurance) with Special Reference to Erode Rural, Tamilnadu, India, European Journal of Social Sciences - Volume 25, Number 2. pp. 219-232.

Sundar, J. and Ramakrishnan, Lalitha (2010). A Study on Farmers' Awareness, Perception and Willing to Join and Pay for Crop Insurance. International Journal of Business and Management Invention. 2(1): 48-54.

Suresh Kumar, D., et al., (2011) An Analysis of Farmers' Perception and Awareness towards Crop Insurance as a Tool for Risk Management in Tamil Nadu, Agricultural Economics Research Review, Vol. 24 January-June 2011, pp. 37-46.

\section{How to cite this article:}

Chakraborty, S., S. Ghosh, U. Rai, S. Panda, L. Das, P. K. Pal and Mondal, S. 2020. Attitude of Farmers towards Crop Insurance in Coochbehar District of West Bengal. Int.J.Curr.Microbiol.App.Sci. 9(09): 2776-2779. doi: https://doi.org/10.20546/ijcmas.2020.909.344 